Pengembangan Rekayasa dan Teknologi, Vol 15, No. 1, Juni 2019, pp 33-37

p-ISSN: $1410-9840$ \& e-ISSN: 2580-8850

http://journals.usm.ac.id/index.php/jprt/index

\title{
PENGEMBANGAN APLIKASI MOBILE UNTUK TRY OUT UJIAN NASIONAL MATEMATIKA PADA SISWA SMK KELAS XII
}

\author{
Yulinda Kusumaningrum ${ }^{1}$, Titis Handayani ${ }^{2}$, Nur Wakhidah ${ }^{3}$ \\ ${ }^{1}$ Sistem Informasi Universitas Semarang, ${ }^{2}$ Teknik Informatika Universitas Semarang, \\ ${ }^{1}$ yulinda@usm.ac.id, ${ }^{2}$ titis@usm.ac.id, ${ }^{3}$ ida@usm.ac.id
}

\begin{abstract}
ABSTRAK
Saat ini pemerintah Indonesia akan memajukan mutu dan kualitas sumber daya manusia. Salah satu caranya adalah dengan memberikan perhatian khusus terhadap pendidikan di Indonesia. Ujian berstandar nasional merupakan kebijakan pemerintah dalam bidang pendidikan untuk menentukan standar mutu pendidikan. Matematika merupakan salah satu mata pelajaran yang nilai kelulusannya paling sedikit dibandingkan dengan mata pelajaran lainnya. Hal tersebut dibuktikan dengan menurunnya nilai UN matematika di SMK Perdana selama dua tahun terakhir. Menurunnya nilai UN salah satunya disebabkan karena kurangnya pendalaman konsep, berupa uji coba (tryout) yang diberikan oleh pihak sekolah. Padahal mata pelajaran matematika mengharuskan siswa untuk sering berlatih dalam mengerjakan soal.

Aplikasi Mobile merupakan salah satu alternatif yang sangat potensial untuk dikembangkan saat ini. Dengan media aplikasi mobile ini di harapkan para siswa mampu melakukan tryout ujian nasional untuk mata pelajaran matematika kapan pun dan dimana pun. Dan aplikasi menyediakan menu pembahasan soal. Sehingga siswa dapat memperdalam serta semakin memahami soal-soal matematika. Hal tersebut akan berdampak pada kesiapan siswa dalam mengerjakan ujian nasional khususnya mata pelajaran matematika.
\end{abstract}

Keywords: Aplikasi Mobile, tryout, matematika

\section{Pendahuluan}

Matematika merupakan salah satu mata pelajaran yang nilai kelulusannya paling sedikit dibandingkan dengan mata pelajaran lainnya. Berdasarkan wawancara dengan salah satu guru kelas XII di SMK Perdana Semarang diperoleh nilai ujian nasional untuk mata pelajaran matematika selama 2 tahun terakhir mengalami penurunan. Salah satunya disebabkan karena kurangnya pendalaman konsep, berupa uji coba (tryout) yang diberikan oleh pihak sekolah. Padahal mata pelajaran matematika mengharuskan siswa untuk sering berlatih dalam mengerjakan soal, sehingga siswa akan terbiasa dalam mengerjakan soal matematika tanpa harus menghafalkan rumus.

Selain itu, tryout yang diadakan pihak sekolah menggunakan tes tertulis. Hal ini memiliki beberapa kekurangan seperti dalam hal waktu yang diberikan oleh guru akan sedikit berkurang dengan adanya kegiatan membagikan lembar soal. Begitupun dari segi pembuatan lembar soal-soal latihan yang membutuhkan banyak kertas dan biaya untuk membuat lembar soal-soal latihan tersebut. Selain itu, para siswa harus menunggu beberapa hari untuk mengetahui hasilnya karena sistem pengkoreksian yang masih manual. Mengoreksi jawaban dengan cara manual juga menyebabkan guru mengalami kesulitan untuk mengetahui jenis soal yang dianggap sulit bagi siswa. Oleh karena itu, diperlukan suatu alternatif yang dapat digunakan untuk mengatasi keterbatasan waktu yang dimiliki oleh pihak sekolah serta memudahkan guru untuk melakukan evaluasi terhadap jenis soal yang dianggap sulit oleh siswa.

Aplikasi Mobile merupakan salah satu alternatif yang sangat potensial untuk dikembangkan saat ini. Hal ini didasarkan pada fakta yang ada bahwa jumlah penggunaan perangkat mobile untuk aktivitas di internet semakin meningkat. Aplikasi mobile sekarang sudah banyak digunakan sebagai media dalam pendidikan. Selain itu, banyak siswa SMK yang menggunakan smartphone dalam kesehariannya. Sejalan dengan Sobirin (2015) menyatakan bahwa dengan menggunakan aplikasi mobile learning untuk try out SMA memudahkan siswa dalam mempersiapkan ujian nasional. Hartono (2014) bahwa dengan aplikasi try out berbasis android siswa dapat mengetahui kemampuannya dan dapat meningkatkan ilmu pengetahuannya. Sehingga siswa dapat lebih siap dalam menghadapi Ujian Nasional. Setyadi (2017) menyatakan bahwa mobile leraning berbasis android yang dikembangkan dapat memotivasi siswa dalam berlatih mengerjakan soal matematika.

Dengan media aplikasi mobile ini di harapkan para siswa mampu melakukan tryout ujian nasional 
untuk mata pelajaran matematika kapan pun dan dimana pun, sehingga siswa dapat memperdalam serta semakin memahami soal-soal matematika. Hal tersebut akan berdampak pada kesiapan siswa dalam mengerjakan ujian nasional khususnya mata pelajaran matematika.

\section{Metode}

Tryout ujian nasional matematika SMK secara tertulis sering dikeluhkan oleh beberapa sekolahan karena memerlukan biaya yang besar. Biaya yang besar tersebut digunakan untuk membeli kertas, fotokopi soal dan lembar jawab. Tryout ujian nasional matematika secara tertulis juga dikeluhkan guru dalam hal pengoreksiannya karena memakan waktu yang lama. Berdasarkan permasalah tersebut diperlukan suatu aplikasi tryout ujian nasional matematika yang dapat membantu memudahkan guru memberikan latihan dan lebih menghemat biaya.

Objek dalam penelitian ini yaitu siwa kelas XII SMK Perdana Semarang tahun ajaran 2018/2019. Aplikasi mobile untuk membantu tryout ujian nasional yang menggunakan metode pengembangan sistem prototype:

1. Identifikasi kebutuhan

Pembuat sistem bersama-sama dengan pengguna dalam hal ini guru pengampu mata pelajaran matematika mendiskusikan kebutuhan aplikasi yang akan dibangun, kemudian mendifinisikan format seluruh perangkat lunak, mengidentifikasikan seluruh kebutuhan, dan garis besar sistem yang akan dibuat.

2. Membangun prototyping

Adalah proses pembuatan rancangan sementara yang berfokus pada penyajian kepada guru pengampu matematika. Contohnya adalah desain form try out dan form pembahasan soal.

3. Evaluasi prototyping

Langkah ini melibatkan pengguna. Dimana pengguna yaitu guru pengampu matematika akan memberikan penilaian, apakah prototype nya sudah sesuai dengan kebutuhan dan keinginan pelanggan. Jika sudah, maka pembuat sistem akan melanjutkan ke langkah berikutnya. Jika belum, maka akan diulang dari langkah 1,2 dan 3 .

4. Coding

Pada tahap ini, setelah semua desain sesuai dengan kebutuhan pengguna, maka akan diterjemahkan ke dalam bahasa pemrograman android studio.

5. Menguji Sistem dan Evaluasi

Setelah aplikasi mobile untuk try out jadi, maka dilakukan ujicoba aplikasi. Dan diamati apakah sudah sesuai dan sudah dapat mengatasi kebutuhan serta kendala lapangan. Uji coba ini menjadi evaluasi bersama antara pengguna dan pembuat sistem.

\section{Implementasi Sistem}

Aplikasi mobile untuk try out yang sudah jadi dan diterima oleh pengguna, siap diimplementasikan.

\section{Hasil dan Pembahasan}

1. Antarmuka Aplikasi try out

Aplikasi mobile untuk try out ujian nasional yang dihasilkan antarmuka yang tampak pada gambar 1 adalah tampilan halaman menu utama, yang berisi menu latihan soal, menu uji coba Paket A, menu uji coba Paket B dan menu Profil Penyusun.

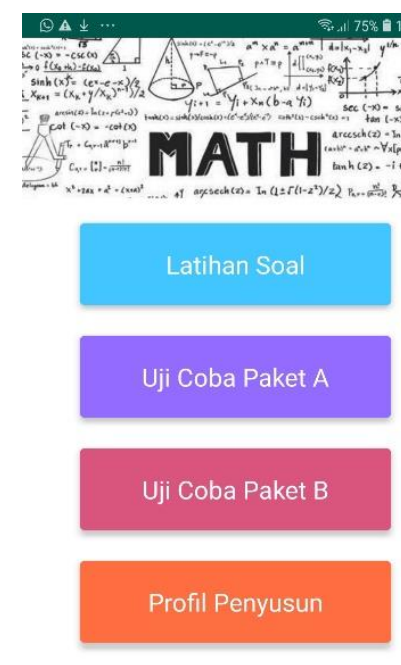

\section{(4) LPM UNIVERSITAS SEMARANG 2019}

Gambar 1. Tampilan Halaman Menu Utama

Pada tampilan ini, Guru memberikan anjuran kepada siswa untuk mencoba memilih menu Latihan Soal terlebih dahulu. Pada menu Latihan Soal, terdapat beberapa ketentuan yaitu soal berjumlah 40 nomor, waktu yang diberikan untuk pengerjaan tidak terbatas dan setiap nomor disertai pembahasan soal seperti yang tampak pada Gambar 2 berikut.

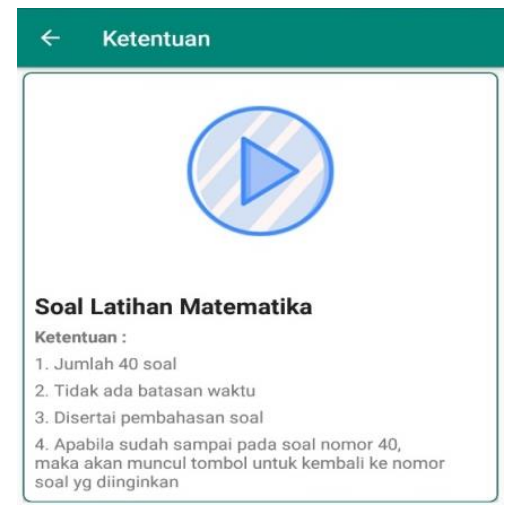

Gambar 2. Tampilan Ketentuan Soal 
p-ISSN: $1410-9840 \&$ e-ISSN: $2580-8850$

Tampilan menu halaman latihan soal dimulai dari soal nomor 1 sampai dengan soal nomor 40 dan dilengkapi dengan (a) 5 check box pilihan jawaban, (b) tombol cek jawaban, yang berfungsi untuk mengetahui jawaban yang di-input-kan bernilai benar atau salah, (c) tombol pembahasan, yang berfungsi untuk menampilkan cara perhitungan jawaban dari soal yang ditampilkan. (d) tombol soal berikutnya, berfungsi untuk menampilkan soal selanjutnya dan (e) tombol refresh, berfungsi untuk refresh dari tampilan soal yang kurang jelas.

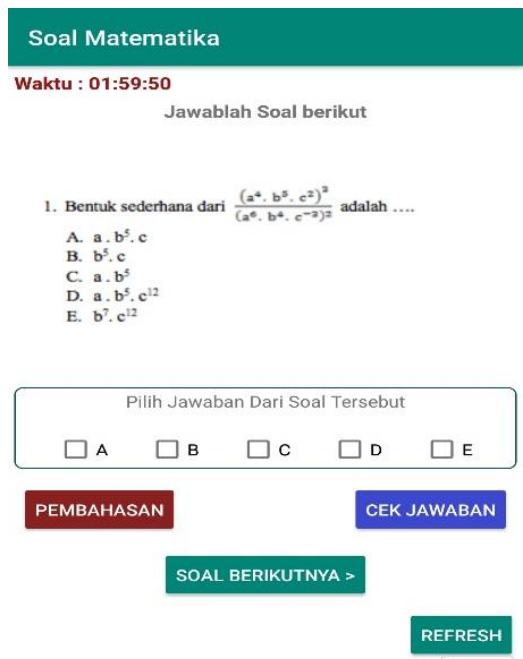

Gambar 3. Tampilan Latihan Soal

Setelah siswa melakukan latihan soal, maka Guru meminta siswa untuk melakukan try out dengan memilih menu Uji Coba Paket A atau menu Uji Coba Paket B yang memiliki soal 40 nomor dengan waktu pengerjaan terbatas selama 120 menit. Setelah siswa memilih salah satu menu uji coba paket, maka tampilan soal paket tampak pada gambar 4. Tampilan soal paket $\mathrm{A}$ atau paket $\mathrm{B}$ memiliki (a) 5 check box pilihan jawaban, (b) tombol soal berikutnya dan (c) tombol refresh.

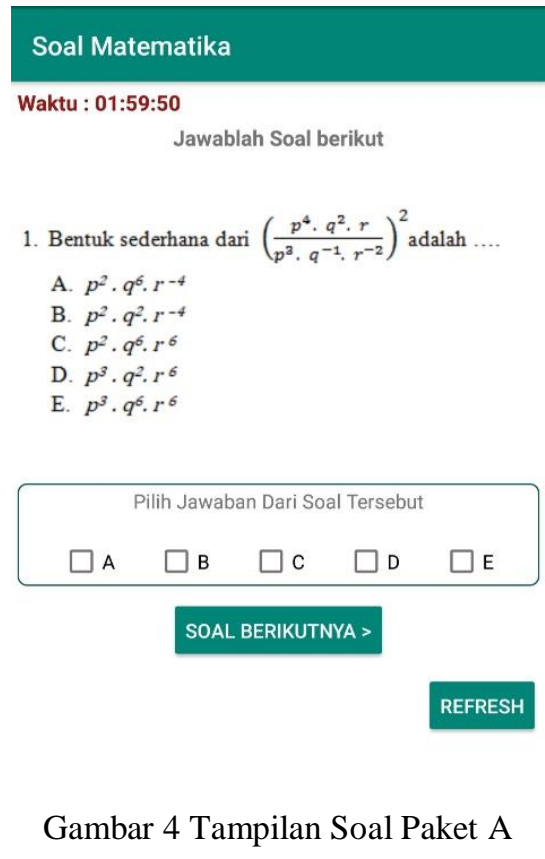

Tampilan terakhir dari aplikasi ini adalah tampilan hasil. Tampilan ini merupakan halaman yang menampilkan rekap dari siswa yang telah mengerjakan soal ujian, yang ditampilkan adalah jumlah soal yang dijawab dengan benar, yang jawaban salah serta total nilai yang diperoleh. Total diperoleh dari jawaban benar dikalikan 10, kemudian dibagi 4 .

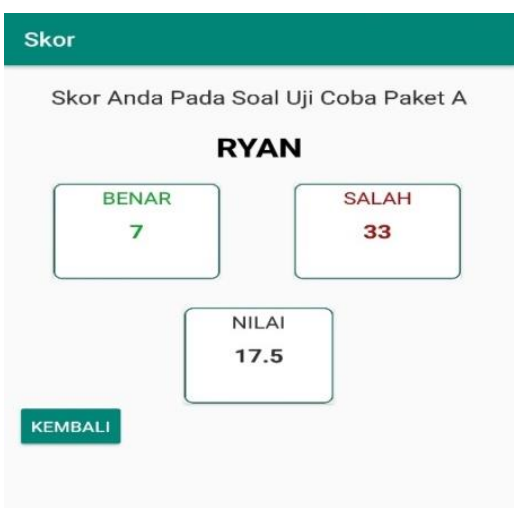

Gambar 5 Tampilan Hasil

2. Hasil Uji Coba tryout menggunakan Aplikasi Mobile

Aplikasi mobile untuk try out yang dihasilkan, di uji coba kan kepada para siswa SMK Perdana Kelas XII sebanyak 30 siswa. Hasil yang diperoleh dari pengerjaan para siswa yang telah melakukan uji coba paket A dan paket B tampak pada tabel 1 dan table 2 berikut; 
Tabel 1. Hasil Try Out Soal Paket A

\begin{tabular}{|c|l|c|}
\hline \multicolumn{3}{|c|}{ Kode Soal A } \\
\hline No & \multicolumn{1}{|c|}{ Nama Siswa } & Nilai \\
\hline 1 & Rida Mayda & 90 \\
\hline 2 & Prihatini sukma & 87.5 \\
\hline 3 & Niam Ulli & 82.5 \\
\hline 4 & Nova Khoirunisa & 80 \\
\hline 5 & Tasya & 80 \\
\hline 6 & Vieke Wanda & 77.5 \\
\hline 7 & Putri catur & 75 \\
\hline 8 & Cantika Wanda & 67.5 \\
\hline 9 & Ananda tasya & 65 \\
\hline 10 & Annisa Oktaviani & 65 \\
\hline 11 & Vina Firdiani & 62.5 \\
\hline 12 & Dinda Wulandari & 52.5 \\
\hline 13 & Tiara Rosita & 52.5 \\
\hline 14 & Nanda okta & 50 \\
\hline 15 & Nur Amalia & 50 \\
\hline
\end{tabular}

Tabel 2. Hasil Try Out Soal Paket B

\begin{tabular}{|c|l|c|}
\hline \multicolumn{3}{|c|}{ Kode Soal B } \\
\hline No & Nama Siswa & Nilai \\
\hline 1 & Dewi Safitri & 92.5 \\
\hline 2 & Angga & 90 \\
\hline 3 & Khusnul & 90 \\
\hline 4 & Hanifah & 87.5 \\
\hline 5 & Nuradilla & 85 \\
\hline 6 & Nadia D & 80 \\
\hline 7 & Devanka & 80 \\
\hline 8 & Adila Janita & 77.5 \\
\hline 9 & Novitasari & 75 \\
\hline 10 & Dinar Dwi & 67.5 \\
\hline 11 & Tri Retno & 65 \\
\hline 12 & Awaliyah & 55 \\
\hline 13 & Aprilia Nilam & 55 \\
\hline 14 & Ita Agustina & 52.5 \\
\hline 15 & Affiah & 50 \\
\hline
\end{tabular}

Berdasarkan data diatas, nilai tertinggi untuk kode soal B diperoleh siswa Rida Mayda dengan skor 90 dan nilai terendah diperoleh siswa Nur Amalia dengan skor 50. Sedangkan nilai tertinggi untuk kode soal C diperoleh siswa Dewi Safitri dengan skor 92.5 dan nilai terendah oleh Affiah dengan skor 50.

\section{Hasil Kuesioner Penggunan Aplikasi Mobile}

Kuesioner yang digunakan untuk mengukur penggunaan aplikasi mobile dalam tryout ujian nasional matematika menggunakan 10 buah pernyataan. Kuesioner diberikan kepada 30 siswa dan responden memandang tinggi atau baik aplikasi mobile sebagai media dalam membantu tryout ujian nasional matematika. Hal ini terbukti dengan rata-rata tanggapan responden yang menjawab setuju artinya bahwa indikator-indikator yang mewakili penggunaan aplikasi mobile mendapat tanggapan positif bagi siswa SMK kelas XII dalam mempersiapkan tryout ujian nasional matematika. Hasil kuesioner tampak pada tabel 3 .

Tabel 3.Hasil Kuesioner Penggunaan Aplikasi Mobile

\begin{tabular}{|c|c|c|c|c|c|c|c|}
\hline No & Pernyataan & $\begin{array}{l}\text { SS } \\
\text { (4) }\end{array}$ & $\begin{array}{c}\text { S } \\
\text { (3) }\end{array}$ & $\begin{array}{l}\text { KS } \\
\text { (2) }\end{array}$ & $\begin{array}{l}\text { TS } \\
\text { (1) }\end{array}$ & $\mathrm{Jml}$ & $\begin{array}{l}\text { Rat- } \\
\text { rata }\end{array}$ \\
\hline \multirow[t]{2}{*}{1} & \multirow[t]{2}{*}{ X.1 } & 15 & 14 & 1 & 0 & 30 & \multirow[t]{2}{*}{3.46} \\
\hline & & 60 & 42 & 2 & 0 & 104 & \\
\hline \multirow[t]{2}{*}{2} & \multirow[t]{2}{*}{ X.2 } & 10 & 20 & 0 & 0 & 30 & \multirow[t]{2}{*}{3.33} \\
\hline & & 40 & 60 & 0 & 0 & 100 & \\
\hline \multirow[t]{2}{*}{3} & \multirow[t]{2}{*}{ X.3 } & 18 & 12 & 0 & 0 & 30 & \multirow[t]{2}{*}{3.60} \\
\hline & & 72 & 36 & 0 & 0 & 108 & \\
\hline \multirow[t]{2}{*}{4} & \multirow[t]{2}{*}{ X.4 } & 16 & 13 & 1 & 0 & 30 & \multirow[t]{2}{*}{3.50} \\
\hline & & 64 & 39 & 2 & 0 & 105 & \\
\hline \multirow[t]{2}{*}{5} & \multirow[t]{2}{*}{ X.5 } & 15 & 13 & 2 & 0 & 30 & \multirow[t]{2}{*}{3.43} \\
\hline & & 60 & 39 & 4 & 0 & 103 & \\
\hline \multirow[t]{2}{*}{6} & \multirow[t]{2}{*}{ X.6 } & 17 & 11 & 1 & 1 & 30 & \multirow[t]{2}{*}{3.46} \\
\hline & & 68 & 33 & 2 & 1 & 104 & \\
\hline \multirow[t]{2}{*}{7} & \multirow[t]{2}{*}{ X.7 } & 10 & 12 & 5 & 3 & 30 & \multirow[t]{2}{*}{2.97} \\
\hline & & 40 & 36 & 10 & 3 & 89 & \\
\hline \multirow[t]{2}{*}{8} & \multirow[t]{2}{*}{ X.8 } & 11 & 11 & 5 & 3 & 30 & \multirow[t]{2}{*}{3.00} \\
\hline & & 44 & 33 & 10 & 3 & 90 & \\
\hline \multirow[t]{2}{*}{9} & \multirow[t]{2}{*}{ X.9 } & 16 & 13 & 1 & 0 & 30 & \multirow[t]{2}{*}{3.53} \\
\hline & & 64 & 39 & 3 & 0 & 106 & \\
\hline \multirow[t]{2}{*}{10} & \multirow[t]{2}{*}{ X.10 } & 15 & 12 & 2 & 1 & 30 & \multirow[t]{2}{*}{3.36} \\
\hline & & 60 & 36 & 4 & 1 & 101 & \\
\hline
\end{tabular}

IV. Kesimpulan

Dari Penelitian ini maka diperoleh beberapa kesimpulan yaitu:

1. Aplikasi mobile dalam tryout ujian nasional matematika dapat membantu memudahkan siswa SMK kelas XII dalam mempersiapkan ujian nasional.

2. Respon siswa untuk aplikasi mobile tryout ujian nasional matematika sangat baik.

3. Aplikasi ini memberikn contoh soal dan juga pembahasan soal, sehinggan siswa dapat mengetahui kesalahan dalam pengerjaan soal.

Adapun Saran yang dapat diberikan dari hasil penelitian ini yaitu:

1. Penelitian ini dapat dilanjutkan dengan pembuatan aplikasi mobile untuk tryout mata pelajaran lain seperti bahasa Indonesia atau bahasa inggris.

2. Penelitian ini dapat dilanjutkan dengan pembuatan aplikasi mobile berbasis e-learning 
sehingga terjadi interaksi diskusi antara siswa dengan guru.

\section{Daftar Pustaka}

Ally, M. 2009. Mobile learning: transforming the delivery of education and training. Edmonton: AU Press.

Arifpurnamayana, M. I. 2012. Rancangan dan Pembuatan Mobile Learning Berbasis Android. [Online]. Diakses pada http://repository.gunadarma.ac.id.

Nazruddin Safaat H. 2013. Aplikasi berbasis android. Informatika : Bandung.

Hartono, Toto. 2014. Aplikasi Simulasi Try Out Ujian Nasional Berbasis Android untuk SMA. [Online]. Diakses pada http ://elib.unikom.ac.id

Sobirin. 2015. Pengembangan aplikasi mobile learning Sebagai media alternatif persiapan ujian nasional Siswa sekolah menengah atas (SMA). [Online]. Diakses pada http ://eprints.uny.ac.id.

Setyadi, Danang. 2017. Pengembangan Mobile learning berbasis android sebagai sarana berlatih mengerjakan soal matematika. [Online]. Diakses pada https://www.researchgate.net/publication/32257 5973. 